\title{
In-Service Teacher Training Project On Inquiry-Based Practical Chemistry
}

\author{
Päivi Tomperi \\ Unit of Chemistry Teacher Education, Department of Chemistry, University of Helsinki • \\ paivi.tomperi@helsinki.fi \\ Maija Aksela \\ Unit of Chemistry Teacher Education, Department of Chemistry, University of Helsinki
}

\begin{abstract}
The aim of study is to support meaningful practical chemistry learning and research-based teaching at the upper secondary level by designing a model for in-service teacher training. Teachers were introduced the SOLO (= Structure of the Observed Learning Outcome) taxonomy as a tool to estimate the quality of learning attainable for students when performing laboratory tasks according to written instructions that exist in the chemistry books. Research methods employed in this empirical case study were materials produced by teachers, questionnaire for the participants after training and interview of one teacher. The data is analyzed by methods of qualitative content analysis. The main results from the study give information about the implementation of the revised training model in which teachers worked collaboratively and that the SOLO tool succeeded in raising teachers' awareness of how the written instructions can reflect the student performance in a laboratory. Teachers became familiar with classifying laboratory assignments to the various SOLO levels and understood how using only the verification type of tasks at school would not help students to develop their higher order cognitive skills (HOCS). Nevertheless, only one teacher out of three presented teacher-experimented material according to training goals. The most challenging phase of the voluntary training was the personal implementation of instructional material. Educational design research is a methodical study of designing, developing and evaluating educational programs, processes and results. We shall discuss the results obtained from the second design experiment and introduce the revised model for the in-service teacher training.
\end{abstract}

Keywords practical chemistry, inquiry, educational design research, the SOLO taxonomy

\section{Introduction}

The starting point for the in-service teacher training is the prevailing situation at upper secondary level, where teachers use most of their time on content coverage and employ on the average two practical chemistry lessons in one course. Therefore, it has a great significance, how these few practical lessons will be carried out. Participating teachers were asked to email the trainer in advance the written instructions of their favorite laboratory task in the form as given to their students. It gave information about the participants and helped to assess the level where training should be established. The ultimate goal of the project is to improve practical chemistry education at upper secondary level and to promote inquiry-based teaching and learning. For students to learn to use inquiry in science, their teachers need to be well oriented in inquiry and inquiry-based methods. To urge teachers to 
try inquiry-based instructional strategies in problem-solving tasks teachers were introduced the SOLO taxonomy (Biggs \& Collis, 1982) as a tool to evaluate the quality of instructional material used to recognize the level of learning they correspond to in order to make informed decisions about the laboratory work they employ at the course.

The evaluation of the results of the first case study led to changes in this second implementation of the in-service teacher training. Because teachers had expressed the need for more training with inquiry-based instruction and how to apply the SOLO taxonomy in the modification of laboratory tasks, one extra day was added to the second training course. Instead of individual projects, as occurred in the first training, participating teachers worked in collaboration where they could better engage in active dialogue about inquirybased teaching and learning in practical chemistry.

\section{Theoretical background}

According to research findings, there is a strong relationship between teachers' educational beliefs and their actions in practice. (Pajares, 1992; Kagan, 1992; Luft, 2001; 2007, Bryan, 2003, Wallace \& Kang, 2004) Teacher beliefs are known to act as filters through which teachers respond to the teaching and learning situations. Teacher's practical knowledge is "constructed by teachers in the context of their work integrating experiential knowledge, formal knowledge and personal beliefs" (van Driel, Beijaard, \& Verloop, 2001, p.137). Practical theories that guide teachers in teaching are based on practical knowledge which is considered as "the core of a teacher's professionality" (van Driel \& al., 2001, p.142). Teachers' practical theories often include beliefs about science, effective teaching and learning, teachers' orientation toward science teaching and the ability of their students (Lotter, Harwood, \& Bonner, 2007). Because teacher beliefs can act as constraints or supports to implementing new innovations, they are recommended to be taken into account in the execution of the in-service teacher training programs (van Driel \& al., 2001; Blanchard \& al., 2009). Within a constructivist learning and teaching framework beliefs about teaching and learning should be acknowledged during training if the innovation is to make difference in the deep structure of knowledge and beliefs held by learners (Richardson, 1996). Teacher-centered beliefs emphasize the factual and descriptive nature of science as determined by the teacher and transferred to the student. Teachers consider that their responsibility is to organize the scientific knowledge to the student. Studentcentered beliefs place the responsibility of acquiring and processing information on the student. (Roehrig \& Luft, 2004)

Lifelong learning is a strategy for updating the qualifications of the workforce and it "provides individuals with opportunities to enhance their ability to stay longer on the labour market and develop themselves throughout their life and career" (Välimaa, 2006, 48). Clarke \& Hollingsworth (1994) have identified six alternative perspectives on teacher change and later they suggested that the focus of teacher professional training efforts should closely align with the change as growth or learning where teachers themselves are 
learners who work in the classroom through professional activity. Change is seen as a complex process in which teachers are active learners shaping their professional growth. There are four analytical interconnected domains in their model as presented in Figure1: external source of information, professional experimentation, teacher knowledge, beliefs and attitudes, and salient outcomes. Change in one domain is associated with change in another by two processes, namely, enactment of a new form of pedagogical practice modeled in the in-service training and reflection. The model shows that there can be several cycles of enactment and reflection between the domain of practice and the personal domain (arrows $2-7$ ) before any reflection associated with consequences (arrow 8) and any change in beliefs (arrow 9) takes place. According to their model, it is pivotal to any change in teacher beliefs and attitudes how teachers themselves interpret the change, not what others, e.g. trainer, consider as a change, concerning the teacher experimentation. (Clarke \& Hollingsworth, 2002)

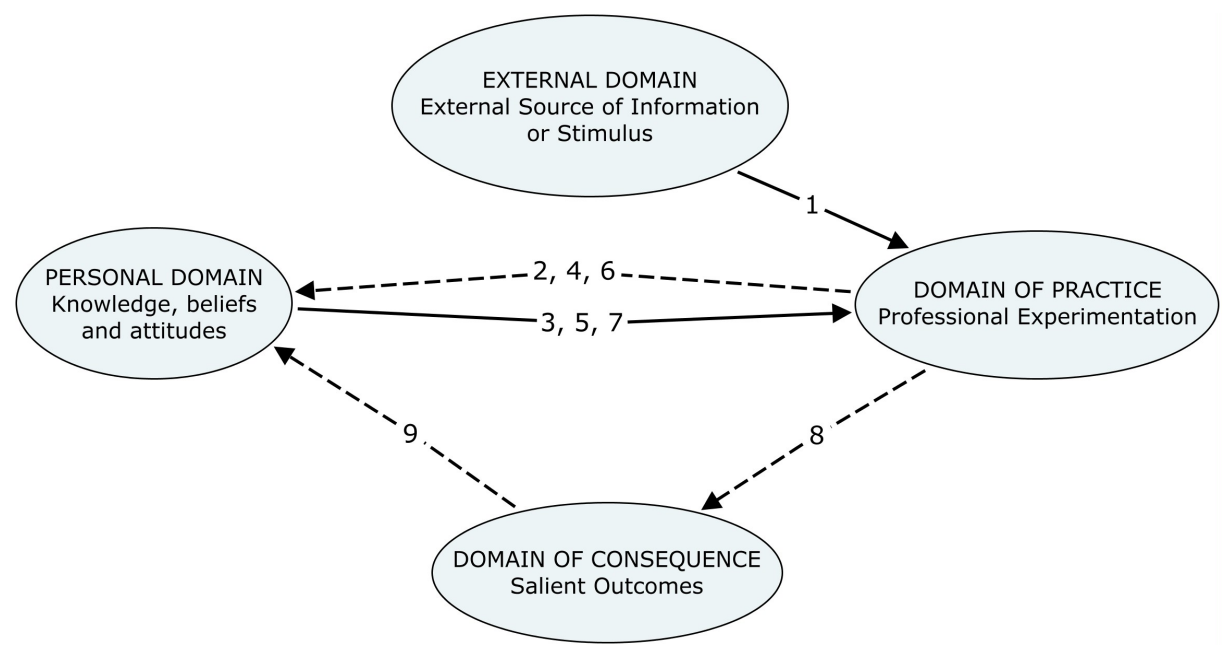

Figure 1 Multiple growth network according to Clarke and Hollingsworth (2002)

\subsection{The solo taxonomy}

Biggs and Collis (1982) created the Structure of the Observed Learning Outcome (= SOLO) taxonomy, which is based on the Piaget's sequence of cognitive development reflecting the understanding of science at five hierarchic levels where each level builds at the skills that were acquired at previous one. The SOLO taxonomy is designed as a means to classify the quality of responses (rather than students) in various disciplines from mathematics to accounting and in chemistry education it has been used in analyzing responses of exams in organic chemistry (Hodges \& Harvey, 2003) and of computer supported assignments (Kiviahde, 2005). Evaluation of written laboratory instructions using the SOLO taxonomy may reveal if activities carried out in the laboratory support only superficial learning and do not encourage students to proceed towards deeper learning by providing opportunities for development of HOCS. Laboratory work should not be the goal in itself but the learning experience, which provides means to students' mental activity (Bybee, 2006). Biggs and 
Collis (1982) described five levels of the learning outcomes on the basis of the structural organization of the knowledge in question from incompetence to expertise in hierarchical order (Table 1).

Table 1 Description of performance within five SOLO levels (adapted from Biggs \& Collis 1982, pp. 24-25) and the hierarchy verbs that parallel the SOLO taxonomy (adapted from Biggs \& Tang 2007, pp. $79-80$ ).

\begin{tabular}{lll}
\hline SOLO level & Relating operation & Examples of verbs \\
\hline Prestructural & $\begin{array}{l}\text { Denial, tautology, transduction. } \\
\text { Misses the point. }\end{array}$ & \\
Unistructural & $\begin{array}{l}\text { Ability to "generalize" only in } \\
\text { terms of one aspect }\end{array}$ & $\begin{array}{l}\text { Identify, name, memorize, quote, } \\
\text { recognize, match, do simple } \\
\text { procedure }\end{array}$ \\
Multistructural & $\begin{array}{l}\text { Ability to "generalize" only in } \\
\text { terms of limited and independent } \\
\text { aspects. }\end{array}$ & $\begin{array}{l}\text { Classify, list, illustrate, select, } \\
\text { sequence, } \\
\text { combine, do algorithms }\end{array}$ \\
Relational & $\begin{array}{l}\text { Induction. Ability to generalize } \\
\text { within given or experienced } \\
\text { context using relating aspects. }\end{array}$ & $\begin{array}{l}\text { Apply, integrate, analyze, predict, } \\
\text { conclude, argue, compare, contrast, } \\
\text { construct, solve a problem, relate }\end{array}$ \\
Extended & $\begin{array}{l}\text { Deduction and induction. Ability } \\
\text { to generalize to situations not } \\
\text { experienced. }\end{array}$ & $\begin{array}{l}\text { Theorize, } \\
\text { generate, create, compose, originate, } \\
\text { invent }\end{array}$ \\
\hline
\end{tabular}

As students learn, the outcomes of their learning display similar stages of enhancing structural complexity (Biggs \& Tang, 2007). Similarly, focusing on learning outcomes in practical chemistry, laboratory instruction can be written using the SOLO taxonomy at five hierarchical categories with increasing difficulty. The first three levels, prestructural, unistructural and multistructural levels, correspond to traditional verification "cook-book" laboratory. They are quantitative in nature, as the amount of detail increases, and they enable the entrance to the qualitative levels for students e.g. by training them to use a new instrument that is needed later in problem solving tasks. As an elementary competence in laboratory education is the ability to follow the written instructions which is needed when laboratory working skills are built up. The quantitative stages of learning occur first, then learning changes qualitatively. Relational and extended abstract SOLO levels are qualitative in nature, as the collected details become integrated into a structural pattern, and they correspond to the various types of inquiry. Which level of inquiry is employed depends on 
students' capabilities; the greater the skill level and the knowledge of students, the higher the level of inquiry can be employed.

One task that was modified by a teacher during the training course is given as an example in Table 2. This simple laboratory work illustrates the law of conservation of mass and the law of constant composition. The original instruction (A) from the chemistry text book (Lehtiniemi \& Turpeenoja, 2005) represents conventional verification style. The

Table 2 Original task (A) and the corresponding modified task (B) created by the participating teacher to accommodate inquiry-based approach.

\section{Determination of Empirical Formula}

A. Original task from the chemistry textbook

\section{Empirical formula for magnesium oxide}

Objective:

Determination of empirical formula for ionic compound experimentally.

Equipment and substances needed: magnesium ribbon $\mathrm{Mg}(\mathrm{s})$, sand paper, crucible cover, tongs, clay triangle, heating equipment (picture given), desiccator if available for cooling, accurate balance.

\section{Procedure:}

1. Clean $2 \mathrm{~cm}$ piece of $\mathrm{Mg}$-ribbon with sandpaper and record its mass.

2. Record the mass of an empty crucible. 3. Fold the Mg-ribbon to fit into the bottom of the crucible. Heat the open crucible until Mg-ribbon ignites.

4. Lid the crucible leaving it slightly open and heat for about five minutes more.

5 . Cool the crucible in desiccator.

6 . Weigh the crucible after cooling.

Handling of the results:

1. What is the substance that magnesium reacts with?

2. Calculate the amount of product formed

in grams.

3. Calculate how many grams of oxygen reacts with magnesium.

4. Calculate the number of moles of magnesium atoms.

5. Calculate the number of moles of oxygen atoms.

6. What is the ratio between the moles of reacting magnesium and oxygen?

7. What is the empirical formula of the compound formed based on the previous step?

\section{B. Task modified by the teacher}

\section{Determination of empirical formula experimentally}

A compound consists only of magnesium and oxygen. Make a plan of how to

investigate

experimentally the empirical formula for this compound. Present your plan to the teacher. After the teacher has accepted it, you will proceed to execute your plan.

After finishing your study complete and return to the teacher a summary that contains
a) your observations
b) calculations,
c) conclusions,
d) possible sources of error.

(Fill in the group evaluation table given.) 
procedure in A is given on the prestructural SOLO level and the handling of the results on the multistructural level with isolated step-by-step phases. Modified task (B) on the relational SOLO level requires the learners to create their own procedure. It will have to contain the details given in the original task but the isolated components in the procedure need to be integrated to form a coherent whole. The concepts of combustion and empirical formula need to be restructured in the learner's mind in order to find out how they are related to generate practical steps for the procedure through which the intended outcome can be obtained. The benefit for producing instructions at different SOLO levels is that they give chance for differentiation: those learners who are not motivated to do inquiry can be guided to work according to step-by-step instruction. Sometimes after offering learners an opportunity to work on the qualitative SOLO levels which call for the use of HOCS (i.e. planning, constructing, hypothesizing, composing, etc.), they can be directed to continue with detailed instructions on the quantitative SOLO level to keep the time table.

\section{Research methodology}

\subsection{Educational design research}

The aim of educational design research (EDR) is to produce usable knowledge about educational practice. Emphasis is on conducting research in authentic educational context with desire for research to have practical impact. It uses theory-driven design to generate interventions that can be improved through multiple cycles of design, enactment and study. (Pernaa, 2013) The design project is recommended to report in several phases (Juuti \& Lavonen, 2006). The reports dealing with the need's assessment and the results of the first case study have been reported earlier (Tomperi \& Aksela, 2008; 2009; 2011; 2012). The results documented here were obtained from the second intervention which was the empirical case study of the in-service teacher training course Promoting Inquiry-Based Practical Chemistry Teaching. It employs materials produced by the teachers, data obtained through questionnaire after the training and interview of one teacher. The design and development of the training is a process with two iterative design research cycles of problem analysis, design, implementation and evaluation. (Edelson, 2002) Three types of data is obtained: design methodology about the design process of how the SOLO tool can support teachers in developing practical chemistry lessons; problem analysis reveals the obstacles that exist on the way of new practices, and design solution will support in-service teachers in the implementation of inquiry approach. The data from the interview were analyzed by the methods of qualitative content analysis.

\subsection{Research questions}

The overall project aims at finding answers to the following research questions:

1. How does inquiry-based practical chemistry teaching suit the upper secondary level?

2. What advantage does the SOLO tool bring to the practical chemistry teaching? 
3. What kind of model suits the in-service teacher training in practical chemistry?

\subsection{IN-SERVICE TEACHER TRAINING MODEL}

A revised model (Figure 2) of the designed voluntary training course was carried out for three in-service chemistry teachers at upper secondary level during one spring term. They all had 8-12 years of teaching experience at upper secondary level. During the first meeting in January 2012 teachers were introduced the SOLO tool and in the workshop they used it for analyzing and modifying their favorite laboratory tasks of which they had send written instructions to the trainer as a pre-task to the course. During the second meeting two weeks later teachers selected together laboratory tasks from chemistry course books and modified them collaboratively mainly to the structured and guided inquiry type of assignments to experiment with at schools. During the final meeting in May 2012 teachers shared their experiences of experimenting at school. Between the three meetings the trainer/researcher was available for tutoring by email or by telephone if needed.

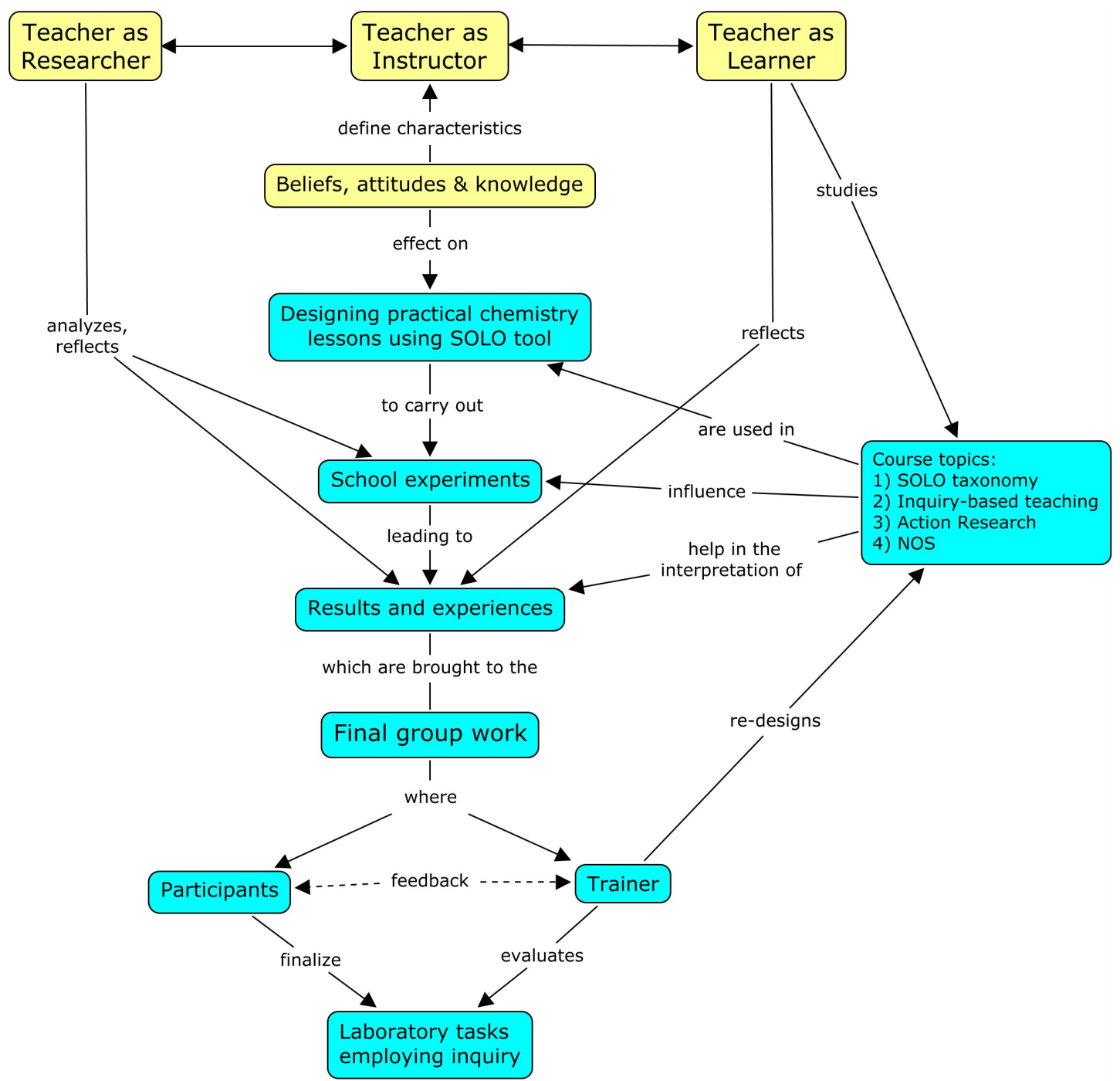

Figure 2 Concept map of the revised in-service teacher training model 
The goals for the in-service training course were 1) to introduce SOLO tool to improve the quality of written instructions in "hands-on" practical chemistry 2) to help teachers to create an inquiry lab from traditional step-by-step lab by modifying collaboratively laboratory instructions using the SOLO tool 3) to inform teachers up-to-date research findings in chemistry education and 4) to introduce action research methodology to acquire personal experiences of inquiry.

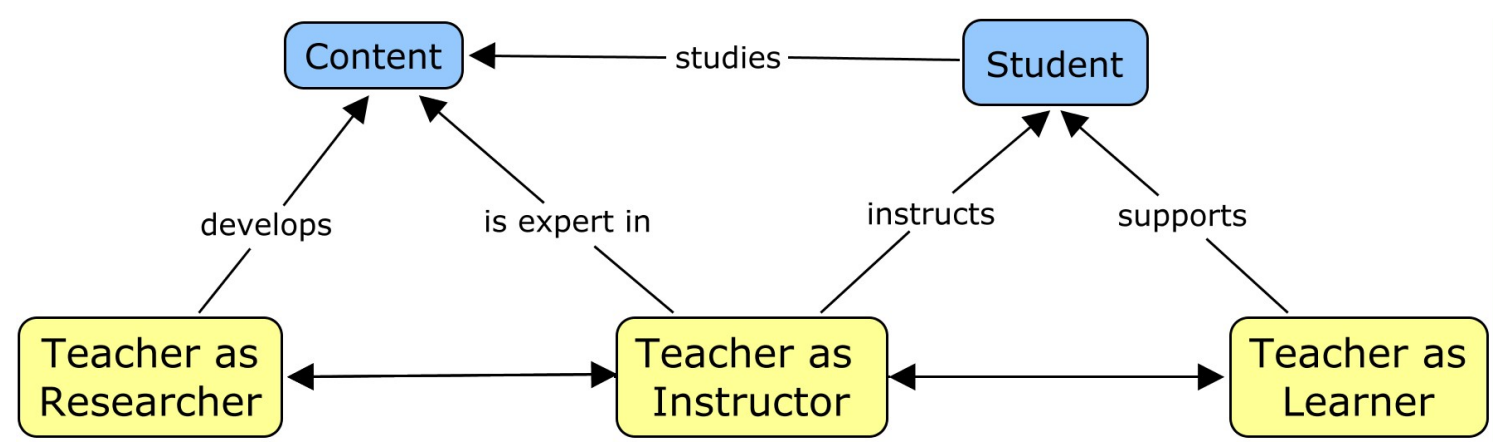

Figure 3 The didactic triangle and the three roles of the teacher

The starting point of the model is applied from the didactic triangle by Herbart showing the relation between the student, the teacher and the content (Figure 3). The model stresses the balance between the three roles of the teacher as an instructor, as a learner and as a researcher (Tomperi \& Aksela, 2012). Teacher as researcher means a teacher as a practitioner researcher where teacher does research on her/his own work. In the Finnish teacher education the goal is to train teachers as researchers and lifelong learners capable of reflecting their own work to afford professional growth (Niemi \& Jakku-Sihvonen, 2009). Participating teachers were encouraged to use action research methodology as a professional inquiry to improve their understanding of practice. (Carr \& Kemmis, 1982) Reflection is an essential component of lifelong learning because it can expose and challenge beliefs and underlying assumptions concerning teaching and learning. According to literature the educational innovation efforts will be unsuccessful unless the teacher's knowledge and beliefs, which are often implicit, are taken into account. Teachers need to restructure their knowledge and beliefs and based on the reflection of their teaching experiences using new instructional material, integrate the new information in their practical knowledge. Ability to reflect both in action and on action is the trademark of the competent teacher (Niemi \& al., 2009).

\section{Results and discussion}

Design solutions describe the resulting design. The experiences of participants are presented to evaluate design solutions. Change involves learning and the interview aimed at getting a glimpse of the way one teacher construed the meaning of the educational change proposed to him and how he grasped the SOLO tool. 
In discussions during training teachers expressed positive attitudes towards inquirybased teaching and learning but considered structured and guided inquiry approach to be feasible at upper secondary level. In the content analysis of the interview the statements related to the first research question were selected and organized to form categories. Three categories were found: 1) the modification of tasks, 2) student-centered approach and 3) teacher experiences and attitudes.

According to Lotter \& al. (2007) teachers' conceptions of science, their students, effective teaching practices and the purpose of education influence the type and amount of inquiry instruction that is implemented in the classrooms. When discussed with interviewee, he showed clear understanding about the meaning of inquiry and how it can be fostered by open laboratory assignments. He had especially given students opportunities to plan how to investigate certain phenomena, which conventional laboratories tend to neglect. He described the process of modifying the tasks: "The structure of the original task was completely broken as if it was modified back to the manuscript of what to investigate." On the other hand, when he was asked about the role of laboratory work in general, he stressed how the laboratory work and demonstrations are used to verify science concepts by demonstrating the relationship between particular concept and phenomena. The interviewee also held the belief that not all the students are capable of inquiry and the view of effective teaching as transmission of facts to students and these both are known as constraints concerning the use of inquiry-based practices. Additionally, the purpose of education to prepare students for the matriculation examination has strong influence on restricting the use of inquiry instruction. The driving force for the experimenting with inquiry for the interviewee could be the expressed pedagogical discontentment with his current practical chemistry practices (Southerland, Sowell, \& Enderle, 2011).

The interview revealed a common belief that only the good students would be able to execute inquiry assignments (Feldman, 2002; Roehrig \& al., 2004): "The modified task may be too open (i.e. too difficult) but it may as well have been a matter of good luck that I got a group of students who understood what it (inquiry) is about." The interviewee had witnessed, much to his own surprise, only students' positive attitudes towards inquiry. Experimentation of inquiry had also raised insecurity in him which is an expected reaction: "It may take more experimentation and several student groups to see the change (in practices)." As a consequence of inquiry-based teaching experimentation, studentcenteredness had increased in the classroom practices at least temporarily which was revealed by statements like "If I had not succeeded with all the groups (to do inquiry) I would have modified the task further" and "In the previous task, for example, students were goal oriented (with an attitude) that now let's start experimenting”. Interestingly too, during one inquiry-based experimentation students had ignored teacher's attempts of scaffolding revealing the existing view of the ideal learner who does not need any guidance from the teacher or negotiate with the teacher during the execution of the laboratory 
assignment but solves the given problem alone or, as in this case, in a small group, without any help from outside to secure the best possible grade.

The SOLO tool showed the teachers that written instructions at low SOLO level demonstrated low student achievement in laboratory and as a consequence they were motivated to tailor instructional material into more open type of problem solving tasks corresponding qualitative SOLO levels. Based on answers given in the questionnaire, teachers thought, that the SOLO tool would make their work easier by helping them to find a suitable laboratory work or to modify one from the existing instructional material into a new task according to learning goals. One teacher replied to the questionnaire: "I shall look instructions now with new eyes".

The goal of producing teacher-tested material on different SOLO levels was reached by one teacher and he was chosen for interview to tell about his experiences with SOLO tool. In the interview the teacher told, that he had found the SOLO taxonomy to be useful for him, for example: "The significance of the SOLO tool in the future comes surely from my capacity to compare new instructions which I shall introduce in the subsequent courses". He told that the prerequisite had been that the used material already existed in the chemistry textbooks but modifying written instructions into suitable SOLO levels increased his sense of ownership. The SOLO tool had also opened the concept "inquiry" to the teacher and justified to him the need to employ inquiry approach in laboratory education: "When you introduced the SOLO taxonomy, the different levels of taxonomy made sense to me and I began to think that employing conventional laboratory tasks only wouldn't take students' whole potential in use".

The results here and in the previous cycle are in line with research that even though teachers are convinced of the benefits of the new innovation, it does not mean that they will change their practices (Supovitz \& Turner, 2000; Feldman, 2002). To enhance their competence in strategies to translate inquiry understanding into classroom practice teachers were supported to develop their own materials and to revise the existing ones (Schwartz \& Lederman, 2002). Engagement in personal experimentation at schools became the challenging phase at the voluntary in-service training course. Only one teacher out of three presented teacher tested material in the final meeting which signifies that beliefs remained intact. In order the innovation to succeed teachers need to be provided with reasons they can believe, that will become part of their practical theories and that are visible from reflection on their practice. (Feldman, 2002) Especially they need assistance to reflect on their roles as learners and researchers according to constructivist epistemology and evidence-based teaching and learning. This is something that school organization need to focus in order to support sustained development. According to socio-cultural theory personal beliefs have been developed socially and within the context of the school culture and therefore, the school culture impact decisions about inquiry-based science teaching (Wallace \& Kang, 2004). The next phase would be to involve principal and teacher 
colleagues in the development process to encourage individual teachers to use the new instructional material they have created using the SOLO tool and gain experience with inquiry instead of adapting new material to fit traditional practices. (Friedman \& Kass, 2002; Dillon, 2000)

\section{References}

Biggs, J. B., \& Collis, K. F. (1982). Evaluating the quality of learning: the SOLO taxonomy. Academic Press: New York.

Biggs, J. B., \& Tang, C. (2007). Teaching for quality learning at university. McGrawHill, $3^{\text {rd }}$ edition.

Blanchard, M. R., Southerland, S. A., \& Granger, E. M. (2009). No silver bullet for inquiry: Making sense of teacher change following an inquiry-based research experience for teachers. Science Education, 93(2), $322-360$.

Bryan, L. A. (2003). Nestedness of beliefs: Examining a prospective elementary teacher's belief system about science teaching and learning. Journal of Research in Science Teaching, 4O(9), 835 -868 .

Bybee, R. W. (2006). Scientific inquiry and science teaching. In L.B. Flick \& N.G. Lederman (Eds.) Scientific inquiry and nature of science. Implications for teaching, learning and teacher education (pp.1 - 14). Springer.

Carr, W., \& Kemmis, S. (1982). Becoming critical: Knowing through action research. Victoria: Deakin University.

Clarke, D. J., \& Hollingsworth, H. (1994). Reconceptualising teacher change. In G. Bell, B. Wright, N. Leeson, \& J. Geake (Eds.) Challenges in mathematics education: Constraints on construction, Vol 1. Proceedingsof the 17th annual conference of the mathematics education research group of Australasia (pp.153 - 164). Lismore, NSW: Southern Cross University.

Clarke, D., \& Hollingsworth, H. (2002). Elaborating a model of teacher professional growth. Teaching and Teacher Education., 18(8), 947 - 967.

Dillon, J. (2000). Managing science teachers' development. In R. Millar, J. Leach, \& J. Osborne (Eds.) Improving Science Education. The Contribution of Research. (pp. 94 - 109) Open University Press.

Edelson, D. C. (2002). Design research: What we learn when we engage in design. The Journal of the Learning Sciences, 11(1), $105-121$.

Feldman, A. (2002). Multiple perspectives for the study of teaching: Knowledge, reason, understanding, and being. Journal of Research in Science Teaching, 39(10), 1032 - 1055.

Friedman, I. A., \& Kass, E. (2002). Teacher self-efficacy: a classroom-organization conceptualization. Teaching and Teacher Education, 18(6), 675 - 686.

Hodges, L. C., \& Harvey, L. C. (2003). Evaluation of student learning in organic chemistry using the SOLO taxonomy. Journal of Chemical Education, 8o(7), $785-787$.

Juuti, K., \& Lavonen, J. (2006). Design-based research in science education: One step forwards methodology. NorDiNa, 4, 54-68.

Kagan, D.M. (1992). Implications of research on teacher belief. Educational Psychologist, 27(1), 65 90.

Kiviahde, M. (2005). Effects of authentic learning and e-learning in an introductory chemistry laboratory course. (Doctoral dissertation). Acta Universitatis Ouluensis. (A 444)

Lehtiniemi, K., \& Turpeenoja, L. (2005). Mooli 2. Kemian mikromaailma KE2. Otava

Lotter, C., Harwood, W. S., \& Bonner, J. J. (2007). The influence of core teaching conceptions on teachers' use of inquiry teaching practices. Journal of Research in Science Teaching, 44(9), 1318 -1347 . 
Luft, J. A. (2001). Changing inquiry practices and beliefs: the impact of an inquiry-based professional development programme on beginning and experienced secondary science teachers. International Journal of science Education, 23(5), 517 - 534.

Luft, J. A., \& Roehrig, G. H. (2007). Capturing science teachers' epistemological beliefs: the development of the teacher beliefs interview. Electronic Journal of Science Education, 11(2), 38 63 .

Niemi, H., \& Jakku-Sihvonen, R. (2009). Teacher education curriculum of secondary school teachers. Revista de educacion, 350, 173 - 202.

Pajares, M. F. (1992). Teachers' beliefs and educational research: Cleaning up a messy construction. Review of Educational Research, 62(3), 307 - 332.

Pernaa, J. (2013). Kehittämistutkimus tutkimusmenetelmänä. In J. Pernaa (Ed.) Kehittämistutkimus opetusalalla (pp. 9 - 26). Juva: PS-kustannus Opetus 2000.

Richardson, V. (1996). The role of attitudes and beliefs in learning to teach. In J. Sikula (Ed.) Handbook of Research on Teacher Education (pp. 102 - 119). New York: MacMillan.

Roehrig, G. H., \& Luft, J. A. (2004). Constraints experienced by beginning secondary science teachers in implementing scientific inquiry lessons. International Journal of Science Education, 26(1), 3 24.

Southerland, S. A., Sowell, S., \& Enderle, P. (2011). Science Teachers' pedagogical discontentment: Its sources and potential for change. Journal of Science Teacher Education, 22, 437 - 457.

Supovitz, J. A., \& Turner, H. M. (2000). The effects of professional development on science teaching practices and classroom culture. Journal of Research in Science Teaching, 37(9), 963 - 980.

Schwartz, R. S., \& Lederman, N. G. (2002). 'It's the nature of the beast': The influence of knowledge and intentions on learning and teaching the nature of science. Journal of Research in Science Teaching, 39, $205-236$.

Tomperi, P., \& Aksela, M. (2008). Tutkimuksellinen kemian kokeellinen oppiminen lukiossa. In J. Välisaari, \& J. Lundell (Eds.) Kemian opetuksen päivät 20o8: Uusia oppimisympäristöjä ja ongelmakeskeistä oppimista (pp. 113 - 118). Jyväskylän yliopiston kemian laitoksen tutkimusraportti No.129.

Tomperi, P., \& Aksela, M. (2009). Lukion kemian pakollisen kurssin oppikirjojen laboratoriotöiden analysointi käyttäen SOLO taksonomiaa. In M. Aksela, \& J. Pernaa (Eds.) Arkipäivän kemia, kokeellisuus ja työturvallisuus kemian opetuksessa perusopetuksesta korkeakouluihin (pp. 152 159). IV Valtakunnalliset kemian opetuksen päivät - Symposiumikirja.

Tomperi, P., \& Aksela, M. (2011). Opettajien kokeellisten laboratoriotöiden valinnat. In M. Aksela, J. Pernaa, \& M. Happonen (Eds.) Kansainvälinen kemian vuosi: Kemia osaksi hyvää elämää (pp. 84 - 95). VI Valtakunnalliset kemian opetuksen päivät - Symposiumikirja.

Tomperi, P., \& Aksela, M. (2012). Promoting inquiry-based practical chemistry using SOLO taxonomy. Proceedings ICCE-ECRICE, CnS XXXIV-3, 388 - 392.

van Driel, J. H., Beijaard, D., \& Verloop, N. (2001) Professional development and reform in science education: the role of teachers' practical knowledge. Journal of Research in Science Teaching, $38(2), 137-158$.

Välimaa, J. (2006). Analysing the relationship between higher education institutions and working life in a Nordic context. In P. Tynjälä, J. Välimaa, \& G. Boulton-Lewis (Eds.) Higher education and working life - Collaborations, confrontations and challenges (pp. 35 - 53). Elsevier Ltd.

Wallace, C. S., \& Kang, N.-H. (2004). An investigation of experienced secondary science teachers' beliefs about inquiry: An examination of competing belief sets. Journal of Research in Science Teaching, 41(9), $936-960$. 